SJ Quinney College of Law, University of Utah Utah Law Digital Commons

Utah Law Faculty Scholarship

Utah Law Scholarship

2016

\title{
Indians, Race, and Criminal Jurisdiction in Indian Country
}

Alexander Tallchief Skibine

University of Utah, SJ Quinney College of Law, alex.skibine@law.utah.edu

Follow this and additional works at: http://dc.law.utah.edu/scholarship

Part of the Criminal Law Commons, Criminal Procedure Commons, and the Indian and Aboriginal Law Commons

Recommended Citation

10 Alb. Govt. L. Rev. 49 (2017)

This Article is brought to you for free and open access by the Utah Law Scholarship at Utah Law Digital Commons. It has been accepted for inclusion in Utah Law Faculty Scholarship by an authorized administrator of Utah Law Digital Commons. For more information, please contact valeri.craigle@law.utah.edu. 


\title{
INDIANS, RACE, AND CRIMINAL JURISDICTION IN INDIAN COUNTRY
}

\author{
Alex Tallchief Skibine
}

Which Sovereign, among the Federal, States, and Indian nations, has criminal jurisdiction in Indian Country depends on whether the alleged perpetrator and/or the victim qualify as an "Indian" for the purposes of certain federal laws. ${ }^{1}$ Criminal jurisdiction in Indian Country is mostly determined by four federal laws, none of which have a specific definition of "Indian." 2 Not only is there no consensus among the Circuits concerning who qualifies as an "Indian," 3 but there has recently been a debate among jurists about whether the classification of "Indian" for the purposes of these criminal laws amounts to a racial classification calling upon courts to review such classifications using strict scrutiny. ${ }^{4}$

When it comes to criminal jurisdiction in Indian Country, some judges as well as commentators have argued that unless the term "Indian" is restricted to people who are officially enrolled members of federally recognized Indian tribes or eligible for such membership, the classification amounts to a racial classification and strict scrutiny should be applicable. ${ }^{5}$ Yet, for years, federal

* S.J. Quinney Professor of Law, University of Utah S.J. Quinney College of Law.

118 U.S.C. $\$ 1151$ (2012) ("Indian Country" today is a term of art that includes all lands within Indian reservations as well as land held in trust or restricted fee by the United States for the benefit of Indians, and lands set aside by the United States for Dependent Indian Communities).

2 Robert N. Clinton, Criminal Jurisdiction Over Indian Lands: A Journey Through a Jurisdictional Maze. 18 Ariz. L. Rev. 503 (1976) (On the intricacies of criminal jurisdiction in Indian Country).

3 See Daniel Donovan \& John Rhodes, To Be or Not to Be: Who is an "Indian Person"?, 73 MonT. L. REv. 61, 66 (2012) (hereinafter, Who is an Indian).

4 See United States v. Zepeda, 792 F.3d 1103, 1111 (9th Cir. 2015); United States v. Maggi, 598 F.3d 1073, 1078 (9th Cir. 2010); United States v. Stymiest, 581 F.3d 759, 764 (8th Cir. 2009); United States v. Bruce, 394 F.3d 1215, 1234 (9th Cir. 2005); United States v. Keys, 103 F.3d 758, 761 (9th Cir. 1996); Las Vegas Tribe of Paiute Indians v. Phebus, 5 F. Supp. 3d 1221, 1231 (D.Nev. 2014). All recent cases debating the issue.

5 See Quintin Cushner \& Jon M. Sands, Blood Should Not Tell: The Outdated "Blood" Test Used to Determine Indian Status in Federal Criminal Prosecution, The Fed. LAw., Apr. 2012, at 35 (discussing and agreeing with Judge Rymer's 
courts have not restricted the term "Indian" to enrolled members of Indian tribes but have also included persons of Indian ancestry with substantial ties to Indian communities. ${ }^{6}$ Many scholars and commentators have endorsed such a position. ${ }^{7}$ Although the United States has treated Indians as belonging to a distinct race that fact alone does not transform all legislation treating Indians differently into racial classifications. ${ }^{8}$ The origin of the debate can be traced to Morton v. Mancari where the Court ruled that a federal law giving preference in employment to "Indians" within the Department of Interior's Bureau of Indian Affairs did not amount to a racial classification because it did not give preferences to all "Indians" as a race but only to members of Indian tribes with whom the federal government has a government to government relationship. ${ }^{9}$ As such, the classification was political and not racial. The proper standard of judicial review, therefore, was rational basis review and not strict scrutiny. As further elaborated in this Article, the Mancari decision was not pellucid in explaining the extent and ramifications of its holding. ${ }^{10}$ Furthermore, its rationale seemed to contain some contradictions which have fueled the debate ever since. ${ }^{11}$

The main question addressed in this Article is whether, because of either constitutional or policy reasons, the definition of Indians for the purposes of criminal jurisdiction in Indian Country should now be construed to only include "enrolled" members of Indian tribes. In order to discuss this issue, Part I of this paper gives a brief summary of the laws governing criminal jurisdiction in

dissent in Bruce v. United States, 394 F.3d 1215 (9th Cir. 2005)).

6 See Margo S. Brownell, Who is an Indian? Searching for an Answer to the Question at the Core of Federal Indian Law, 34 U. Mich. J.L. REFoRM 275, 27677 (2001).

7 See Addie C. Rolnick, The Promise of Mancari: Indian Political Rights as Racial Remedy, 86 N.Y.U. L. REV. 958, 995-96 (2011); Brian L. Lewis, Do you Know What you Are? You are What you is; You is What you am: Indian Status for the Purpose pf Federal Criminal Jurisdiction and the Current Split in the Courts of Appeals, 26 HARV. J. RACIAL \& ETHIC Just. 241, 244 (2010); Weston Meyring, "I'm an Indian Outlaw, Half Cherokee and Half Choctaw": Criminal Jurisdiction and the Question of Indian Status, 67 MonT. L. REV. 177, 230 (2006).

8 See Sarah Krakoff, Inextricably Political: Race, Membership, and Tribal Sovereignty, 87 WASH. L. REV. 1041, 1046-47, 1127 (2012); Bethany R. Berger, Reconciling Equal Protection and Federal Indian Law, 98 CAL. L. REV. 1165, 1170 (2010).

9 Morton v. Mancari, 417 U.S. 535, 553-54 (1974).

10 See infra notes 92-114.

11 See Carole Goldberg, What's Race Got to Do with It? The story of Morton $v$. Mancari, in Indian LAW Stories 389 (Kevin K. Washburn et al. eds., 2011). 
Indian Country and explains how the courts have interpreted the term "Indian" for the purposes of these laws. Part II discusses how the Supreme Court determines whether a classification of "Indian" amounts to a racial classification, and suggests what test should be applied to make such determinations. After applying that test to the definition of "Indian" in federal criminal laws regulating jurisdiction in Indian Country, Part III discusses what definition of "Indian" makes the most sense from a policy perspective, taking into account the current federal policies towards Indian tribes, as well as the realities of law enforcement in Indian Country.

\section{CRIMINAL JURISDICTION IN INDIAN COUNTRY}

\section{A. The Statutory Scheme}

Although federal criminal laws of general applicability are generally applicable in Indian Country, ${ }^{12}$ a few federal criminal laws are specifically applicable only in Indian Country. The five major laws are the Indian Country Crimes Act (also known as the General Crimes Act), ${ }^{13}$ The (Indian) Major Crimes Act, ${ }^{14}$ Public Law 280, ${ }^{15}$ the statute generally known as the Duro Fix, ${ }^{16}$ and the 2013 Amendments to the Violence Against Women Act (VAWA). ${ }^{17}$

The Indian Country Crimes Act (ICCA) has its origins in the early Indian Trade and Intercourse Acts of the 1790's and was amended into its final and current form in 1854.18 It extended the general criminal laws of the United States over any offense committed in Indian Country, but contains three exceptions: (1) crimes committed by Indians against other Indians; (2) crimes committed by Indians against anyone if such Indian perpetrator has already been punished under the laws of the tribe; and (3) any case where by treaty stipulations, the exclusive jurisdiction over such offenses has been reserved to the Indian tribe. ICCA is

12 See United States v. Farris, 624 F.2d 890, 896-97 (9th Cir. 1980).

1318 U.S.C. § 1152 (2012).

1418 U.S.C. $\S 1153$ (2012).

1528 U.S.C. $§ 1360$ (2012); 83 Pub. L. No. 280 (1953).

16 Pub. L. No. 101-511, 104 Stat. 1856 (1990) (codified at 25 U.S.C. $§ 1301(2)$ (2012)).

17 Pub. L. No. 113-4., 127 Stat. 54 (codified in relevant part at 25 U.S.C. 1304, and 18 U.S.C. $117(\mathrm{a})$.

18 Regulation of Trade and Intercourse with Indian Tribes, 1 Stat. 137 (1790). On the evolution of criminal jurisdiction in Indian Country see, Robert N. Clinton, Development of Criminal Jurisdiction over Indian Lands: The Historical Perspective, 17 ARIz. L. REV. 951, 955 (1975). 
generally understood as only affecting "interracial" crimes. ${ }^{19}$

The Major Crimes Act (MCA) was enacted in 1885 as a reaction to a Supreme Court decision which held that the federal government did not have jurisdiction under the Indian Country Crimes Act to prosecute one Indian for the murder of another Indian when the crime took place in Indian Country. ${ }^{20}$ The Indian Major Crimes Act extended federal criminal jurisdiction over any Indian who committed any of (originally) seven major crimes against any other person, Indian or non-Indian. ${ }^{21}$

Public law 280 was enacted in $1953 . .^{22}$ In provisions relevant to the subject at hand, the law transferred to designated states the criminal jurisdiction previously exercised by the federal government pursuant to the Indian Country Crimes Act and the Indian Major Crimes Act. ${ }^{23}$ P.L. 280 did not provide a separate definition for "Indian."

In 1991, Congress enacted what is popularly known as the "Duro Fix" as a response to the Court's 1990 decision in Duro v. Reina which held that Indian tribes, by virtue of their status as domestic dependent nations within the United States, had been implicitly divested of criminal jurisdiction over Indians who were not members of the prosecuting tribes. ${ }^{24}$ The "Duro Fix" reaffirmed and restored the "inherent power of Indian tribes . . to exercise criminal jurisdiction over all Indians." 25 More important for the purpose of this Article, the "Duro Fix" defined "Indian" to mean "any person who would be subject to the jurisdiction of the United States as an Indian under [the Indian Major Crimes Act] if that person were to commit an offense listed in that section in Indian country." 26 The legislative choice made in 1991 to incorporate by reference the meaning of "Indian" from a previous law which itself

\footnotetext{
19 Indian Country Crimes Act (codified at 18 U.S.C. $§ 1152$ (2012)).

20 See Ex parte Crow Dog, 109 U.S. 556, 557, 572 (1883).

21 See generally, Kevin K. Washburn, Federal Criminal Law \& Tribal SelfDetermination, 84 N.C. L. REV. 779, 824 (2006).

22 Act of Aug. 15, 1953, Pub. L. No. 67, Stat. 588, (codified as amended at 18 U.S.C. $§ 1162$ (2012), 25 U.S.C. $§ 1321-26$ (2012)).

2383 PUB. L. No. 280, supra note 15 (this regulation did not transfer to the states the criminal jurisdiction exercised by the federal government pursuant to criminal laws of general applicability). It also did not confer any civil regulatory authority to the states. See generally, Duane Champagne \& Carole Goldberg, CaPtured Justice: Native Nations AND Public Law 280 (2012).

24 See Duro v. Reina, 495 U.S. 676, 679 (1990) (The Court had previously ruled that Indian tribes did not have criminal jurisdiction over non-Indians). But see Oliphant v. Suquamish Indian Tribe, 435 U.S. 191 (1978).

2525 U.S.C. $\$ 1301(2)(2016)$.

2625 U.S.C. $§ 1301(4)(2016)$.
} 
did not define the term was puzzling, to say the least, and invited litigation over that issue. For instance in In Re: Duane Gervais, ${ }^{27}$ a federal district court held that the petitioner/defendant was not an Indian for the purpose of the Duro fix, and therefore, the tribe did not have criminal jurisdiction over him. At least one scholar has advocated that the definition of "Indian" for the purposes of the Duro fix should be different than it is for the purposes of the ICCA and MCA. ${ }^{28}$

Finally, in 2013, Congress amended the Violence Against Women Act to restore tribal jurisdiction over non-Indians who commit crimes of domestic violence against tribal Indians while in Indian Country. Just as in the Duro fix, the Amendments did not provide a new definition of "Indian." 29

Although there are no substantive differences concerning who qualifies as an Indian under ICCA or the IMCA, there are procedural differences. In a typical ICCA prosecution, the defendant can either be an Indian accused of committing a crime against a non-Indian or a non-Indian accused of having committed a crime against an Indian. Defendants in both situations have the initial duty to raise their status, or the one of their victims (as an Indian or a non-Indian), as an affirmative defense to the federal prosecution, and carry the initial burden of production for that issue by a preponderance of the evidence. The burden then shifts to the government to disprove the defense beyond a reasonable doubt. In a prosecution under the Indian Major Crimes Act, the defendant's Indian status is an essential element of the government's case which the government must prove beyond a reasonable doubt. ${ }^{30}$

\section{B. The FEDERAL COMmon LAW AdDitions}

In addition to denying tribal criminal jurisdiction over non-

27 In re Garvais, 402 F. Supp. 2d 1219, 1226 (2004).

28 See Addie C. Rolnick, Tribal Criminal Jurisdiction Beyond Citizenship and Blood, 39 AM. IND. L. REV. 337 (2016) (recommending that tribal criminal jurisdiction should be determined by a Community Recognition Standard, meaning anyone who is recognized by the Tribe as a member of the community) (hereinafter Rolnick, Beyond Citizenship and Blood).

29 Violence Against Women Reauthorization Act of 2013, 127 Stat. at 121-22 (codified at 25 U.S.C. section 1304).

30 See United States v. Zepeda, 792 F.3d 1103, 1114 (9th Cir. 2015). 
Indians ${ }^{31}$ and non-member Indians, ${ }^{32}$ the Supreme Court also made an important federal common law ruling concerning state jurisdiction over crimes committed by non-Indians against other non-Indians. In United States v. McBratney 33 the Court held that upon being granted statehood, the state of Colorado obtained criminal jurisdiction over its own citizens throughout the whole State. Therefore, it had jurisdiction over crimes committed by nonIndians against other non-Indians in Indian Country. After first stating that the Act which granted statehood to Colorado necessarily repealed any existing treaty inconsistent with it, ${ }^{34}$ the Court reasoned that, "whenever, upon the admission of a State into the Union, Congress has intended to except out of it an Indian reservation, or the sole and exclusive jurisdiction over that reservation, it has done so by express words." 35 Furthermore, the Court used the equal footing doctrine, which guarantees admission of new states on an equal footing with the original states, to conclude that Colorado "has acquired criminal jurisdiction over its own citizens and other white persons throughout the whole of the territory within its limits." 36

The Court never explained why Indian treaties were inconsistent with the Colorado Statehood Act. ${ }^{37}$ Furthermore, the cases cited as precedents for its statement that whenever it wanted to reserve exclusive jurisdiction over an Indian reservation, Congress in the past had used express words, do not stand for this principle. ${ }^{38}$ One can even question the continuing validity of the decision after later decisions specifically rejected reliance on the Equal Footing doctrine to abrogate tribal rights. ${ }^{39}$

Although it is too late in the day for the Court to reverse this 135 year old flawed reasoning, McBratney has a meaningful impact today if one decides to limit the definition of "Indian" to people who are enrolled tribal members or eligible for enrollment. That is because under that narrower definition of "Indian," all

31 Oliphant v. Suquamish Indian Tribe, 435 U.S. 191, 208 (1978).

32 Duro v. Reina, 495 U.S. 676, 679 (1990) (legislatively overturned by the Duro Fix, 25 U.S.C. § 1301(4) (2016)).

33 United States v. McBratney, 104 U.S. 621, 624 (1881).

34 Id. at 623.

35 Id. at $623-24$.

36 Id. at 624 .

$37 \mathrm{Id}$. at 623.

38 Kan. Indians, 72 U.S. 737, 756 (1866); United States v. Ward, 28 F. Cas. 397, 398 (1863).

39 See United States v. Winans, 198 U.S. 371, 382-83 (1905); Minnesota v. Mille Lacs Band of Chippewa Indians, 526 U.S. 172, 206 (1999). 
crimes committed by non-enrolled "Indians" against non-Indians or other non-enrolled Indians would transfer to state jurisdiction since they would become crimes by non-Indians against other nonIndians.

\section{The Case Law Defining Who is an "Indian" Under the Federal Criminal Jurisdiction Statutes}

\section{The Rogers Test}

The current test adopted by most courts today to determine who qualifies as an Indian for the purpose of criminal jurisdiction in Indian Country is frequently referred to as the Rogers test because it originated with the 1845 Supreme Court decision of United States $v$. Rogers. ${ }^{40}$ The case involved the federal prosecution of Rogers, a white man accused of having killed another person within Cherokee territory. Rogers argued that he had become a citizen of the Cherokee Nation and, therefore, the federal government had no jurisdiction over him since the prosecution was brought under a statute which was a precursor to the ICCA and contained the same exemption for Indians committing crimes against other Indians. ${ }^{41}$ The Supreme Court disagreed, stating:

We think it [is] very clear, that a white man who at mature age is adopted in an Indian tribe does not thereby become an Indian, and was not intended to be embraced in the exception ... The exception is confined to those who by the usages and customs of the Indians are regarded as belonging to their race. [The exception] does not speak of members of a tribe, but of the race generally,-- of the family of Indians. ${ }^{42}$

Although this language can arguably be read as reserving to the tribes the decision of who, under "the usage and customs of the Indians," should be regarded as racially an Indian, this has not been the courts' interpretation. ${ }^{43}$

\footnotetext{
40 United States v. Rogers, 45 U.S. 567, 572-73 (1845).

$41 \mathrm{Id}$. at 572 (interestingly, the victim was also a white man that had become a citizen of the Cherokee Nation).

42 Id. at $572-73$.

43 But see Addie C. Rolnick, Tribal Criminal Jurisdiction Beyond Citizenship and Blood, 39 Am. InDiAn L. REV. 337, 375 (2016) (arguing that tribes should
} 
Although in the wake of Rogers, many courts struggled with determining whether half-blood Indians qualified as Indians. ${ }^{44}$ By 1979, the Ninth Circuit had settled on a two prong test, stating "The test, first suggested in United States $v$. Rogers and generally followed by the courts, considers (1) the degree of Indian blood; and (2) Tribal or governmental recognition as an Indian." 45 In United States v. Bruce, ${ }^{46}$ the Ninth Circuit refined the second prong of the Rogers test. Bruce involved an ICCA prosecution where the defendant was arguing that because she was an Indian who had committed a crime against another Indian, she should have been prosecuted under the MCA and not the ICCA.

The Court endorsed a four factor test to determine if the person should be recognized as an Indian. The four factors are: 1. Tribal enrollment; 2. Government recognition through receipt of assistance reserved only to Indians; 3. Enjoyment of the benefits of tribal affiliation; and 4. Social recognition as an Indian through residence on a reservation and participation in Indian social life. 47

The Ninth Circuit further clarified the meaning of the four Bruce factors in United States $v$. Cruz. ${ }^{48}$ Cruz was prosecuted as an Indian under the MCA but he challenged his status as an Indian. The majority held that the government had not met its burden to show that Cruz was an Indian because although Cruz had enough Indian blood to meet the first prong of the test, he did not meet any of the four factors in the second prong. The Court first confirmed

decide who is an Indian within their community, at least for the purpose of the Duro Fix).

44 See Alberty v. United States, 162 U.S. 499, 501 (1896) (i.e. The Court held that the illegitimate child of a full blood Indian and a black man could not be classified as an Indian).

45 United States v. Broncheau, 597 F.2d 1260, 1262 (9th Cir. 1979).

46 United States v. Bruce, 394 F.3d 1215, 1224 (9th Cir. 2005).

$47 \mathrm{Id}$. at 1223 . The four factor test endorsed by Bruce had been essentially formulated in an earlier case by a federal district court in St. Cloud $v$. United States, 702 F. Supp. 1456 (D.S.D. 1988). After specifying that "The second prong of the Rogers test in essence probes whether the Native American has a sufficient non-racial link to a formerly sovereign people," the St. Cloud court enumerated the four factors adopted later by the Bruce court. St. Cloud v. United States, 702 F. Supp. 1456, 1461 (D.S.D. 1988). The St. Cloud court also added that "These factors do not establish a precise formula for determining who is an Indian. Rather, they merely guide the analysis of whether a person is recognized as an Indian." Id. Although the court found that even though St. Cloud did not meet the first two factors, he would normally be classified as an Indian because he met the last two factors, St. Cloud could not meet the test because he had been enrolled with a tribe which was officially terminated by the federal government. Id. at 1465 .

48 United States v. Cruz, 554 F.3d 840 (9th Cir. 2009). 
that the Bruce factors were to be considered in descending order of importance. ${ }^{49}$ The fact that he was recognized as the descendant of a tribal member and was, as such, eligible for some federal and tribal benefits was not enough to make him an "Indian" because he never took advantage of any of those benefits. ${ }^{50}$ In addition, even though he had lived on the reservation when he was younger, had recently returned and had been prosecuted in tribal Court, he never considered himself an Indian or related to others socially as an Indian by participating in the tribe's cultural life and ceremonies. ${ }^{51}$

Chief Judge Kozinsky authored a dissent which strongly disagreed that the Bruce factors had to be considered in declining order of importance. ${ }^{52} \mathrm{He}$ also took the position that whether one actually took advantage of federal and tribal benefits available to Indians was irrelevant. What was important was that one was judged eligible for such benefits by federal or tribal authorities. ${ }^{53}$ Finally, Judge Kozinski did not agree with the majority that whether one considers oneself an Indian is an important factor.

More recently, the $9^{\text {th }}$ Circuit added some modifications to the Bruce four factor test in the en banc decision in United States $v$. Zepeda. ${ }^{54}$ The Ninth Circuit first clarified that the accused must have a current relationship with a federally recognized tribe and that the tribe was federally recognized at the time of the offense. ${ }^{55}$ Furthermore, as stated in a recent federal district court decision,

Zepeda altered the language of the second factor of the Bruce test and clarified that the factor focuses on whether the individual received assistance reserved only for tribal members or those eligible to become members. This alteration is not trivial as the original language from Bruce tested whether the individual received assistance 'reserved only to Indians[.]'56

As some commentators have noted, other Circuits have adopted

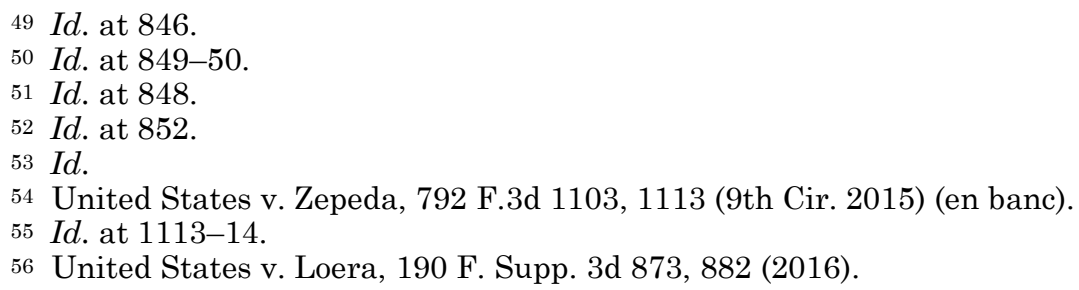


different tests to measure Rogers'Second Prong. ${ }^{57}$ A good example of a slightly different approach is the Eighth Circuit's decision in United States $v$. Stymiest. ${ }^{58}$ In that case, the government had indicted Stymiest under the Indian Major Crimes Act but Stymiest argued that he was not an Indian. The Eighth Circuit first confirmed that although the Indian status of the defendant or the victim was essential to federal subject matter jurisdiction, it was not a jurisdictional issue to be decided by the court as a matter of law. Instead, it was an element of the crime that must be submitted and decided by a jury. The Eighth Circuit went on to adopt its own version for evaluating Rogers' Second Prong, one where the Bruce factors are neither exhaustive, "[n]or should they be tied to an order of importance, unless the defendant is an enrolled tribal member, in which case that factor becomes dispositive."59 In addition, the Stymiest Court held that two factors not listed by the Bruce court, whether the defendant identified himself as an Indian, and whether he subjected himself to the jurisdiction of the tribal court, were in fact relevant to the overall inquiry. 60

\section{Issues with the Blood Quantum Prong}

Under the Rogers test, one cannot be an "Indian" without possessing some quantum of Indian blood although the courts have never formalized how much Indian blood was enough Indian blood. ${ }^{61}$ Although as late as 1968, some cases spoke of "substantial percentage of Indian blood," 62 and later cases seemed to have

57 See Katharine C. Oakley, Defining Indian Status for the Purpose of Federal Criminal Jurisdiction, 35 AM. INDIAN. L. REV. 177 (2010-2011) (describing all the various approaches which have been or might be taken by courts and arguing for a single uniform approach for the sake of consistency and clarity). See also Donovan \& Rhodes, Who is an Indian, supra note 3 (explaining the difference in approaches between the Seventh, Eighth, Ninth, and Tenth Circuits).

58 United States v. Stymiest, 581 F.3d 759, 762 (8th Cir. 2009).

59 Id. at 764.

60 Id. at 763-64. (The Eight Circuit also made the interesting observation that it was troubled by the possibility that under the jury instruction given by the district judge, a jury could find someone to be an Indian without finding that such a person was "recognized as an Indian by the tribe or the federal government." However, since no one had raised any objection, the court concluded that the jury instruction was not an abuse of discretion by the district court judge.).

61 See United States v. Bruce, 394 F.3d 1215, 1227 (9th Cir. 2005) (holding the defendant had $1 / 8^{\text {th }}$ quantum of Indian blood and that was held to be enough to meet the first part of the test).

62 See Makah Indian Tribe v. Clallam County, 440 P.2d 442, 444 (1968) 
lowered the necessary amount to $1 / 8^{\text {th }}$ quantum of Indian blood and perhaps lower. ${ }^{63}$ A further complication concerns the kind of "Indian" blood that qualifies for the purposes of the test. As stated in Bruce, "the first prong requires ancestry living in America before the Europeans arrived." 64 One could surmise that by "America" the Bruce court meant the United States of America, but the meaning is far from clear. In one case, a state court found that a person of Canadian Indian heritage met the first prong of the Rogers test. ${ }^{65}$ But if Canadian Indian blood qualifies, why not Indian blood from tribes aboriginal to Mexico? And if so, how about South and Central America? It seems that for this purpose, the universe of Indian tribes from which Indian blood can be derived should be limited to tribes that are aboriginal to the United States. But what about blood from tribes originating in the United States which no longer exist, have been terminated, or were never recognized by the federal government?

This question provided a spirited debate in a recent Ninth Circuit en banc decision: United States v. Zepeda. ${ }^{66}$ At issue in that case was whether the government had met its burden under the Indian Major Crimes Act to show that the defendant, Zepeda, had "Indian blood." The more recent precedent before Zepeda was United States v. Maggi, ${ }^{67}$ where a panel of the Ninth Circuit held that the quantum of Indian blood must be traceable to a federally recognized Indian tribe. ${ }^{6}$ In its en banc opinion, the Ninth Circuit overruled Maggi and concluded that the "blood" could come from any Indian tribe, recognized or not.

The Court rejected the argument that allowing blood quantum from a non-federally recognized tribe would make federal jurisdiction depend upon a racial rather than a political classification. ${ }^{69}$ Even if it did, the court concluded that the second prong of the Bruce/Rogers test which requires some kind of

(Describing the first prong as requiring "a substantial percentage of Indian blood.").

63 See Bruce, 394 F.3d at 1227. See also Weston Meyring, "I'm an Indian Outlaw, Half Cherokee and Choctaw": Criminal Jurisdiction and the Question of Indian Status, 67 MoNT. L. REV. 177, 202 (2006) (while cases have not been entirely consistent, no cases has held that one could qualify as an Indian with less than $1 / 16^{\text {th }}$ Indian blood quantum).

64 Bruce, 394 F.3d at 1223.

65 State v. Daniels, 16 P.3d 650, 654 (2001).

66 United States v. Zepeda, 792 F.3d 1103, 1109 (9th Cir. 2015).

67 United States v. Maggi, 598 F.3d 1073 (9th Cir. 2010).

68 Id. at $1080-81$.

69 Zepeda, 792 F.3d at 1111. 
recognition as an Indian by, or affiliation with, a federally recognized Indian tribe, "is enough to ensure that Indian status is not a racial classification." 70 Furthermore, noting that the Court in Morton $v$. Mancari had upheld a law which specified that in order to take advantage of the law in question, "an Indian must be one-fourth or more degree Indian blood and be a member of a Federally-recognized tribe," 71 the Zepeda court majority held that the blood quantum prong of the test did not transform the definition of "Indian" into a racial classification. ${ }^{72}$ Judges Kozinski and Ikuta issued vehement dissenting opinions. ${ }^{73}$

Judge Kozinski took issue with the first prong of the Rogers test and even more with the majority's holding that the Indian blood quantum needed to satisfy the first prong does not have to come from a federally recognized Indian tribe. ${ }^{74}$ According to him, overruling Maggi and allowing the necessary blood quantum to come from a non-federally recognized tribe made the Rogers test even worse because "Maggi at least tied the racial component in Bruce to a political relationship." 75 Answering the majority's reliance on the second prong of the Rogers test to salvage its interpretation of the first prong, Judge Kozinski stated "[T]he presence of a separate and independent "non-racial prong' cannot save a test that otherwise turns on race." 76

For Judge Kozinski, it was problematic that some tribal members who satisfied the second prong of the Rogers test could still not be subject to the Major Crimes Act if those members failed the first prong in that they were not racially "Indian enough." 77 In other words, the law would allow Congress to "treat identically situated individuals within a tribe differently from one another based on their immutable racial characteristics."78 Judge Ikuta joined Judge Kozinski in dissent and also added that the first prong of the Rogers test "disrespect tribal sovereignty by refusing to defer to the tribe's own determination of its membership roll.

\footnotetext{
$70 I d$.

71 Id. at 1112 (quoting Morton v. Mancari, 417 U.S. 535, 553, n. 24 (1974)).

72 Id. at 1112 (quoting United v. Antelope, 430 U.S. 641, 646 (1977)).

73 Id. at 1116-20, (Kozinski, J. \& Ikuta, J., dissenting).

$74 \mathrm{Id}$. at 1116.

75 Zepada, 792 F.3d at 1118.

76 Id. at 1117.

77 Id. (Kozinski, J., dissenting) ("But not all tribe members are subject to the IMCA. Separating those who are from those who are not is the function of Bruce's first requirement, and that requirement turns entirely on race.").

78 Id. at 1116.
} 
It's as if we declined to deem a person to be a citizen of France unless that person can prove up a certain quantum of "French blood."79

The dissent acknowledged that one Supreme Court precedent, United States $v$. Rogers, created the blood quantum part of the test but stated that "Reliance on pre-civil war precedent laden with dubious racial undertones seems an odd course for our circuit law to have followed." 80 Judge Kozinski also thought that Rogers could easily be distinguished as a case which just did not allow a white man to claim citizenship in an Indian tribe later in life in order to avoid federal prosecution for murder. ${ }^{81}$ Concerning the majority's reliance that the law at issue in Mancari had a blood quantum, Judge Kozinski just mentioned that "that portion of the provision in Mancari wasn't challenged by plaintiffs, nor was there any assertion that the hiring preference in that case discriminated among tribe members. ${ }^{82}$

The majority argued that it was rational to allow the blood quantum to come from any Indian tribe, recognized or not, because otherwise it would be problematic for the federal government to demonstrate beyond a reasonable doubt that the required blood quantum comes from federally recognized tribes. ${ }^{83} \mathrm{I}$ am not so sure that difficulty in proving something for the purpose of federal prosecution is enough of a reason to impose what seems to be an irrational and arbitrary requirement. If genetic affiliation with a non-recognized tribe is sufficient, would one have to define the universe of "non-recognized" tribes? Would genetic affiliation with a Canadian or Mexican Indian tribe qualify? But if this is so, would it not indicate that the first prong of the Rogers test is really about making sure the person if of the Indian race? Would this not then highlight that "racial" aspect of the classification?

Scholars and commentators have also criticized continuing adherence to the Rogers decision, ${ }^{84}$ and continued adherence to it. ${ }^{85}$

79 Id. at 1119.

80 Id. at 1118. (J. Kozinski dissenting) (Referring to language in Rogers to the effect that the government had to exercise power over this "unfortunate race" in order "to enlighten their minds . . . and to save them if possible from the consequences of their own vices.").

81 Zepada, 792 F.3d at 1118.

$82 \mathrm{Id}$.

83 Id. at 1114-15.

84 Berger, supra note 8, at 2041.

85 See Cushner \& Sands, supra note 5, at 35 (stating "We believe that the two pronged Rogers test ... should be replaced by the simple requirement that a defendant be eligible for enrollment with the relevant federally recognized tribe." 
Although the Rogers decision may have adequately reflected the political leanings and feelings of the times during which it was decided, discarding the decision today would not have any major practical impacts. To start with, discarding the first prong of the test would avoid the awkward possibility raised by Judge Kozinski that an enrolled member from a tribe with no minimum blood quantum requirement would be found not to have "enough" Indian blood to meet the first prong of the test. ${ }^{86}$ Secondly, because all Indian tribes do require their members to have some kind of Indian ancestry, the amount of people who can satisfy the second (recognition) prong of the test while having no Indian blood at all is likely to be infinitesimally small. 87 Third, getting rid of the first prong would eliminate the thorny debate, as highlighted in Zepeda, about whether the Indian "blood" has to be traced to a federally recognized tribe.

Finally, it should put to rest any discussion whether the classification is based on race. ${ }^{88}$

\section{Issues surrounding the Political Recognition Prong}

The second prong allows a person with enough Indian blood to qualify as an "Indian" as long as that person is recognized, politically or socially, as an Indian, by either the federal government, a federally recognized tribal government, or even a recognized Indian community. ${ }^{89}$ More importantly, the second prong allows someone to qualify as an Indian without being officially enrolled or eligible for enrollment in any federally recognized Indian tribe. As stated by the Ninth Circuit:

$$
\begin{aligned}
& \text { [A]lthough an allegation of enrollment may be } \\
& \text { sufficient for purposes of alleging federal }
\end{aligned}
$$

(arguing that treating individual Indians as belonging to a (inferior) race rather than as citizens of Indian nations was crucial to aggrandizing the power of Congress over Indian affairs)).

86 See United States v. Prentiss, 273 F.3d 1277, 1282-83 (10th Cir. 2001) (membership in Tesuque Pueblo is not enough to satisfy Roger's first prong absent evidence that Indian blood was one of the requirements for membership).

87 Frequently Asked Questions, U.S. DEP'T OF THE INTERIOR, BUREAU OF INDIAN AFFAIRS, http://www.bia.gov/FAQs/ (last visited Apr. 13, 2017).

88 But see Jacqueline F. Langland, Indian Status Under the Major Crimes Act, 15 J. GENDER, RACE \& JUST. 109, 131 (2012) (arguing that relying on tribal membership in defining who is an Indian amounts to a racial classification since Tribes require Indian blood to be members).

89 United States v. Zepeda, 792 F.3d 1103, 1114-15 (9th Cir. 2015). 
jurisdiction, ... enrollment has not yet been held to be an absolute requirement of federal jurisdiction ... Nor should it be. Enrollment is the common evidentiary means of establishing Indian status, but it is not the only means nor is it necessarily determinative. ${ }^{90}$

The question here is whether there are any justifications today for not limiting the second prong to enrolled tribal members. Searching the older cases in the wake of Rogers, it seems that jurisdiction was extended to un-enrolled Indians because of essentially two factors. First, it is not until the end of the $19^{\text {th }}$ Century that the idea of having formal tribal membership rolls came into existence. ${ }^{91}$ The very idea of "enrollment through membership rolls" is not part of tribal traditional practices. ${ }^{92}$ Secondly, even though some early tribal membership rolls may have existed by 1885 when the Indian Major Crimes Act was enacted, these "rolls" and all enrollment procedures were created and maintained by the Bureau of Indian Affairs (BIA) and not Indian tribes. Courts became aware that for one reason or another, BIA officials did not place all Indians living on the reservations on official tribal rolls. In Ex Parte Pero v. Pero for instance, ${ }^{93}$ after examining cases where Indians were judicially determined to be Indians even though not present on any tribal membership rolls, ${ }^{94}$ the court stated "[T] he refusal of the Department of Interior to enroll a certain Indian as a member of a certain tribe is not necessarily an administrative determination that the person is not an Indian."95

Although the decision to include in the universe of "Indian" to persons not listed on tribal rolls was initially made out of necessity and for pragmatic reasons, today we are in an era where the tribes

90 United States v. Walter Dale Broncheau, 597 F.2d 1260, 1262-63 (4th Cir. 1979).

91 See Gabriel S. Galanda \& Ryan D. Dreveskracht, Curing the Tribal Disenrollment Epidemic: In Search of a Remedy, 57 ARIZ. L. REV. 383, 393-408 (2015) (describing how and when the concept of "tribal membership" came into being).

92 See Carole Goldberg-Ambrose, Of Native Americans and Tribal Members: The Impact of Law on Indian Group Life, 28 LAW \& SoC'Y REV. 1123, 1127 (1994). 93 See Ex Parte Pero, 99 F.2d 28, 30-33 (7th Cir. 1938).

94 See generally Vezina v. United States, 245 F. 411 (8th Cir. 1917); Sully v. United States, 195 F. 113 (C.C.D.S.D. 1912); United States v. Higgins, 103 F. 348, 348 (C.C.D. Mont. 1900); Doe ex dem. Lafontaine v. Avaline, 8 Ind. 6 (1856).

95 Ex Parte Pero, 99 F.2d at 31. 
themselves have comprehensively taken over the process of maintaining and updating their tribal membership rolls. The question is whether there are any legal or policy reasons to change the test and limit the term "Indian" to enrolled tribal members. As one federal magistrate once stated:

As a practical matter, in light of the Indians' protected status under federal law, the government's treaty obligations, and as a matter of comity to the tribal courts, and as a rational interpretation of the accepted precepts governing tribal sovereignty over tribal members and crimes committed against tribal members on Indian reservations by those acknowledged to be of Indian ancestry, the Court concludes that in using the term "Indian" in section 1152 Congress intended it to mean an Indian who is an enrolled member of a federally-recognized tribe. ${ }^{96}$

Legally, the question is whether constitutional concerns require the term "Indian" to be limited to enrolled tribal members. If the answer is no, the next question is whether the purposes and policies of the federal criminal statutes, as well as current federal policies concerning Indian affairs, would be served by retaining an expanded universe of "Indian" beyond formal enrollment in a tribe. The constitutional issue will be discussed in Part II, the policy one in Part III.

\section{The EQUAL PRotection Issue}

The late Judge Rymer filed a strong dissent in Bruce arguing, among other things, that language used by the Supreme Court in United States v. Antelope, ${ }^{97}$ should compel lower courts to modify Rogers' second prong because "enrollment-or at a minimum, eligibility for enrollment-may be constitutionally required to avoid equal protection problems because otherwise, enforcement of federal criminal laws would arguably be based on an impermissible racial classification."98 The Court in Antelope had

96 United States v. Loera, 952 F. Supp. 2d 862, 879 (D. Ariz. 2013).

97 United States v. Bruce, 394 F.3d 1215, 1234 (9 ${ }^{\text {th }}$ Cir. 2005) (citing United States v. Antelope, 430 U.S. 641, 646 (1977)).

98 Id. at $1233-34$. 
stated:

[F]ederal regulation of Indian affairs is not based upon impermissible classifications. Rather, such regulation is rooted in the unique status of Indians as "a separate people" . . . Federal regulation of Indian tribes, therefore, is governance of oncesovereign political communities; it is not to be viewed as legislation of a "racial' group consisting of 'Indians'. . . ." Indeed, respondents were not subjected to federal criminal jurisdiction because they are of the Indian race but because they are enrolled members of the Coeur d'Alene Tribe. ${ }^{99}$

The Bruce majority never answered Judge Rymer's Equal Protection arguments, stating basically that until such time as they are modified or overruled by an en banc Ninth Circuit opinion, it had to follow circuit precedents which had held that enrollment in a federally recognized Indian tribe was not an absolute requirement.100 It also has to be noted that in a footnote, the Antelope Court acknowledged that "enrollment in an official tribe has not been held to be an absolute requirement for federal jurisdiction, at least where the Indian defendant lived on the reservation and "maintained tribal relations with the Indians thereon." 101 Because the Indians in the Antelope case were enrolled, however, the Court stated that it did not have to intimate any view on whether unenrolled Indians could be subject to the Major Crimes Act. ${ }^{102}$

\section{A. The Jurisprudence of Mancari}

As mentioned earlier, the Court in Morton v. Mancari upheld the constitutionality of a statute granting preference in employment to Indians within the Bureau of Indian Affairs. ${ }^{103}$ Non-Indian federal employees had argued that the preference

99 United States v. Antelope, 430 U.S. 641, 646 (1977).

100 Bruce, 394 F.3d at 1224-25 (relying on United States v. Walter Dale Broncheau, 597 F.2d 1260, 1263 (4th Cir. 1979); United States v. Keys, 103 F.3d 758, 761 (9th Cir. 2005)).

101 Antelope, 430 U.S. at n.7.

102 Id. at n.7.

103 See Morton v. Mancari, 417 U.S. 535, 535 (1974). 
amounted to racial discrimination and should be reviewed under strict scrutiny. ${ }^{104}$ The Court first mentioned that "resolution of the instant issue turns on the unique legal status of Indian tribes under federal law and upon the plenary power of Congress, based on a history of treaties and the assumption of a 'guardian-ward' status, to legislate on behalf of federally recognized Indian tribes." 105 After stating that "The plenary power of Congress to deal with the special problems of Indians is drawn both explicitly and implicitly from the Constitution. . . ."106 the Court mentioned the treaty power and the power to regulate Commerce with the Indian tribes as the source of the Government's power to deal with Indian tribes. ${ }^{107}$ More notably, the Court stated that the Indian Commerce power "singles Indians out as a proper subject for separate legislation.” 108

After mentioning that if laws specifically addressing the concerns of Indians were deemed to be invidious racial classification, literally "an entire Title of the United States Code would be effectively erased. . ." 109 the Court took the position that the preference "does not constitute 'racial discrimination.' Indeed it is not even 'racial' preference," 110 because "[t]he preference, as applied, is granted to Indians not as a discrete racial group, but, rather, as members of quasi-sovereign tribal entities."111 In a footnote, the Court emphasized that because the preference only applied to tribal members and therefore operated to exclude many individuals who were racially Indians but not tribal members, the preference was "political rather than racial in nature." 112 The Court ended up by concluding that "[a]s long as the special treatment can be tied rationally to the fulfillment of Congress' unique obligation toward the Indians, such legislative judgments will not be disturbed." 113 While there are some who thought that

\footnotetext{
104 Id. at 537.

$105 \mathrm{Id}$. at 551.

106 Id. at $551-52$.

$107 \mathrm{Id}$. at 552 .

108 Id. (Article I. Section 8, Clause 3 of the United States Constitution States "The Congress shall have the power to regulate Commerce with foreign Nations, and among the several States, and with the Indian Tribes.").

109 Morton, 417 U.S. at 552.

110 Id. at 553.

$111 \mathrm{Id}$. at 554 .

112 Id. at n.24.

113 Id. at 555. ("Here, where the preference is reasonably and rationally designed to further Indian self-government, we cannot say that Congress' classification violates due process.").
} 
the Court may have been announcing a higher level of rational basis scrutiny in this sentence, ${ }^{114}$ this did not turn out to be the case. ${ }^{115}$

Since Mancari, the Court has evaluated special classification for Native Americans four other times and each time upheld the classification as not being racial but political.116 The more important case for the purpose of this Article is United States $v$. Antelope ${ }^{117}$ where Indians challenged a law that subjected them to a federal criminal law containing a felony murder provision which was not applicable to similar crimes committed by non-Indians and prosecuted under state law.

The Court noted that, unlike Mancari, this law was not promoting tribal self-government but was "dealing, not with matters of self-regulation, but with federal regulation of criminal conduct within Indian country." 118 Yet, the Court concluded that the law was not based upon impermissible racial classifications because Federal regulation of Indian tribes is "rooted in the unique status of Indians as "separate people" ... it is "governance of oncesovereign political communities; it is not to be viewed as legislation of a 'racial' group consisting of Indians."119 Absent from the opinion was any reference to the trust responsibility or whether the law was rationally tied to Congress's unique obligations towards

114 See Ralph Johnson \& E. Susan Crystal, Indians and Equal Protection, 54 WASH. L. REV. 587 (1979).

115 See United States v. Antelope, 430 U.S. 641 (1977). The Court applied traditional rational basis review and stated "respondents do not seriously contend that application of federal law to Indian tribes is so irrational as to deny equal protection." Id. at 647, n.8.

116 See, e.g., Fisher v. District Court, 424 U.S. 382 (1976). The Court held that a law denying Indians access to state courts did not amount to racial discrimination because "[t]he exclusive jurisdiction of the Tribal Court does not derive from the race of the plaintiff but from the quasi-sovereign status of the Northern Cheyenne Tribe." Id. at 390. In the next case, Delaware Tribal Business Committee v. Weeks, 430 U.S. 73 (1977), The Court upheld the distribution of a Court of Claims award that had omitted a class of tribal descendants. Finally, in Washington v. Confederated Bands \& Tribes of Yakima Indian Nation, 439 U.S. 463 (1979), The Court upheld against a due process and equal protection challenge, a federal law (P.L. 280) which granted criminal jurisdiction over some Indian reservations to the state of Washington. The Court stated "It is [well] settled that 'the unique legal status of Indian tribes under federal law' permits the Federal Government to enact legislation singling out tribal Indians, legislation that might otherwise be constitutionally offensive." Id. at $500-01$.

117 Antelope, 430 U.S. at 643-44.

$118 I d$. at 646.

119 Id. 
Indians. Instead, the Court affirmed that laws treating Indians differently cannot be considered racial classifications a long as they involve the governance of Indian tribes. In other words, as long as the laws are enacted pursuant to the Indian Commerce clause or to implement and enforce treaties.

One case, Rice $v$. Cayetano, ${ }^{120}$ refused to apply Morton $v$. Mancari's political classification, but the challenge was to a state law which restricted voting for selection of trustees to the State's Office of Hawaiian Affairs to Native Hawaiians. Even though the definition of Native Hawaiian was expanded to include all persons who had an ancestor living on the Islands before the arrival of the first European in 1778, the Court held that the voting restrictions were unconstitutional under the $15^{\text {th }}$ Amendment to the United States Constitution because "[a]ncestry can be a proxy for race. It is that proxy here." 121 Writing for the majority, Justice Kennedy distinguished Mancari and mentioned that the reason tribal elections established under federal statutes can restrict non-tribal members from voting was because these were elections for the internal governance of quasi sovereign tribes while this case involved elections to a state office. ${ }^{122}$

Interestingly enough, four Justices took the position that if the statute containing the classification of Native Hawaiians was enacted pursuant to a trust responsibility, the classification could not be considered racial. Two of these Justices, Breyer and Souter, took the position that there was no federal trust relationship with Native Hawaiians and that Native Hawaiians did not "sufficiently resemble an Indian tribe." 123 The two other Justices, Stevens and Ginsburg, believed that "the grounds for recognizing the existence of federal trust power here are overwhelming." 124

In the lower courts, the debate surrounding when a law with a specific "Indian classification" may amount to a racial classification has depended on whether the law was enacted

120 Rice v. Cayetano, 528 U.S. 495, 542 (2000).

121 U.S. CONST. amend. XV, $\S 1$ ("The right of citizens of the United States to vote shall not be denied or abridged by the United States or by any State on account of race, or previous condition of servitude."); Cayetano, 528 U.S. at 495.

122 Cayetano, 528 U.S at 520-21.

123 Id. at 525 (Breyer, J., concurring).

124 Id. at 532, 534 (Stevens, J., dissenting) ("The descendants of the Native Hawaiians share with the descendants of the Native Americans . . not only a history of subjugation at the hands of colonial forces, but also a purposefully created and specialized 'guardian-ward' relationship with the United States."). 
pursuant to the Indian trust doctrine, ${ }^{125}$ the Indian Commerce clause, ${ }^{126}$ or affected "uniquely Indian interests." ${ }^{127}$ Concerning this last one, Judge Kozinski stated:

legislation that relates to Indian land, tribal status, self-government, or culture, passes Mancari's rational relation test because 'such regulation is rooted in the unique status of Indians as a "separate people" with their own political institutions' . . . 'as a separate people', Indians have a right to expect some special protection for their land, political institutions . . . and culture. ${ }^{128}$

As further explained in the next section, this Article takes the position that attempting to decide what interests are "uniquely Indian" is taking courts into unchartered territory and ultimately is not a proper judicial task.

\section{B. Distinguishing Between Racial and Political Classifications}

The difficult question in the wake of Mancari has been to determine which legislative classifications of Indians are political in nature and which ones are racial and therefore subject to strict scrutiny. ${ }^{129}$ In light of these difficulties, some scholars have criticized the dichotomy first established in Mancari, and some

125 Alaska Chapter v. Pierce, 694 F.2d 1162, 1169 (9th Cir. 1982) ("If the preference in fact furthers Congress's special obligations, then a fortiori it is a political rather than racial classification even though racial criteria might be used in defining who is an eligible Indian.").

126 See Am. Fed'n of Gov't Emp. v. United States, 330 F.3d 513, 521-22 (D.C. Cir. 2003) (upholding a tribal exception for tribally owned defense contractors).

The critical consideration is Congress' power to regulate commerce 'with the Indian Tribes' ... [R] egulation of commerce with tribes is at the heart of the Clause, particularly when the tribal commerce is with the federal government, as it is here. When Congress exercises this constitutional power it necessarily must engage in classifications that deal with Indian tribes. $I d$.

127 See Williams v. Babbitt, 115 F.3d 657 (9th Cir. 1997).

128 Id. at 664 (quoting United States v. Antelope, 430 U.S. 641,646 (1977)).

129 See Gregory Smith \& Caroline Mayhew, Apocalypse Now: The Unrelenting Assault on Morton v. Mancari, THE FED. LAW., April 2013, at 48 (commentators have noted the many challenges levelled at Mancari's political v. racial classification dichotomy). 
have even argued for its abandonment. ${ }^{130}$ More recently, Professor Sarah Krakoff has suggested that although legislation singling out Indians and Indian tribes have an "obvious" racial component, this does not make such legislation constitutionally suspect on account of race. According to Professor Krakoff, the racial component in Indian legislation comes from the fact that Congress under the Constitution can only establish government to government relationships with groups internal to the United States if the members of this group can establish some ancestral ties or lineage to indigenous people, meaning people or groups who were in existence before the Europeans arrived to America. ${ }^{131}$

This Article does not go as far as advocating the abandonment of the Mancari dichotomy. Instead, this Article takes the position that any legislation enacted pursuant to Congress's Indian Commerce power cannot be considered "racial" because Indians are singled out for special treatment in that Constitutional clause. ${ }^{132}$ Although some have argued that the $14^{\text {th }}$ Amendment was enacted after the Commerce Clause, and as such modified its reach, ${ }^{133}$ others have noted that Section 2 of the $14^{\text {th }}$ Amendment does mention "Indians no taxed" as not being eligible to be counted for the purpose of apportioning congressional seats. ${ }^{134}$ These scholars have argued that this language showed that the drafters of the Amendment did not intend to change previous understandings concerning the status of Indians or the political status of tribes within the United States. ${ }^{135}$

Treating all legislation enacted pursuant to the Indian Commerce Clause as not racial legislation does generate a concern

130 See Sarah Krakoff, Inextricably Political: Race, Membership, and Tribal Sovereignty, 87 WASH. L. REV. 1041, 1059 (2012); Robert Clinton, Isolated in their Own Country: A Defense of Federal Protection of Indian Autonomy and SelfGovernment, 33 STAN. L. REV. 979 (1981); Goldberg, supra note 11; Rolnick, supra note 7; Berger, supra note 7.

131 See Sarah Krakoff, They Were Here First: American Indian Tribes, Race, and the Constitutional Minimum, 69 STAN. L. REV. 491, 537 (2017).

132 This argument has previously been eloquently made by others, see Carole Goldberg, American Indians and Preferential Treatment, 49 UCLA L. REV. 1, 25 (2002).

133 See David C. Williams, The Borders of the Equal Protection: Indians as Peoples, 38 UCLA L. Rev. 759 (1991).

134 The first sentence of section 2 of the $14^{\text {th }}$ Amendment reads "Representatives shall be apportioned among the several States according to their respective numbers, counting the whole number of persons in each State, excluding the Indians not taxed." U.S. CONST. amend. XIV.

135 See Clinton, supra note 130, at 1012; Carole Goldberg, Not Strictly Racial: A Response to "Indians as Peoples", 39 UCLA L. Rev. 169, 175 (1991). 
because the Court has traditionally refused to place any internal limit on Congress's power under the Indian Commerce Clause. ${ }^{136}$ In the next section, I describe the limits that should be placed on Congress's Indian Commerce power.

\section{Limits on Congressional Power Pursuant to the Indian Commerce Clause}

The previous generation of pro-tribal scholars were weary of congressional plenary power being used to control everything inside Indian reservations, thereby infringing unduly on tribal sovereignty. 137 These scholars argued that there had to be some limits to what could be considered "commerce" under the Indian Commerce Clause. ${ }^{138}$ More recently, states rights scholars have been leery of Congress using its Indian Commerce Clause power to regulate Indian related affairs beyond the reservations thereby interfering with state sovereignty. 139 Justice Thomas, for instance, penned a vigorous concurrence in which he strongly argued that Congress had no commerce clause power to enact most sections of the Indian Child Welfare Act (ICWA) because those provisions involved neither trade nor commerce, nor the regulation of Indian tribes. ${ }^{140}$ Concerned that such states' rights argument may endanger some pro-tribal legislation such as ICWA, the next generation of pro-tribal scholars have struck a middle ground, acknowledging some limits to the power of Congress under the

136 This does not mean, however, that there are no external limits imposed by other parts of the Constitution. See Hodel v. Irving, 481 U.S. 704, 718 (1987) (holding that Congress cannot not take Indian property rights without just compensation).

137 See Nell Jessup Newton, Federal Power Over Indians: Its Sources, Scope, and Limitations, 132 U. PA. L. REV. 195, 213 (1984) ("According to the Court, Indian tribes had limited authority over 'internal and social relations' because they were 'semi-independent."'); See, e.g., Robert A. Williams, The Algebra of Federal Indian Law: The Hard Trail of Decolonizing and Americanizing the White Man's Indian Jurisprudence, 1986 WIS. L. REV. 219, 264-65 (1986).

138 See Robert N. Clinton, There is No Federal Supremacy Clause for Indian Tribes, 34 ARIz. ST. L. J. 113, 131 (2002).

139 See Robert G. Natelson, The Original Understanding of the Indian Commerce Clause, 85 DENV. U. L. REV. 201 (2007).

140 See Adoptive Couple v. Baby Girl, 133 S. Ct. 2552, 2570 (2013) (Thomas, J., Concurring) (stating "the portions of the ICWA at issue here do not regulate Indian tribes as tribes," since it applied to "all child custody proceedings involving an Indian child regardless of whether an Indian tribe is involved. This case thus does not directly implicate Congress' power to 'legislate in respect to Indian tribes." (quoting United States v. Lara, 541 U.S. 193, 200 (2004))). 
Indian commerce clause while arguing that the power does extend beyond the regulation of "commercial" affairs and may include the regulation of all interactions, social or commercial, between the tribes or their members, and non-Indians. ${ }^{141}$

Although the Court continues to endorse its 1989 statement that "the central function of the Indian Commerce Clause is to provide Congress with plenary power to legislate in the field of Indian affairs,"142 more recent scholarship has demonstrated this statement to be historically inaccurate. Professor Gregory Ablavsky, for instance, has argued that the Indian Commerce power was "a minor component of a broad Indian affairs power resting on multiple [constitutional] provisions."143 Accepting Professor Ablavsky's findings does not mean that Congress has a free hand in treating Indians differently for all purposes. It is only when acting pursuant to the Indian Commerce Clause, or the treaty power, that Congress can classify Indians differently without such classifications amounting to racial ones. Although the Indian Commerce Clause power may not give unbridled and absolute power to Congress, it is still considerable. ${ }^{144}$ As I have argued elsewhere, for instance, the Trust Doctrine does not limit the Indian commerce power to enact Indian legislation just benefitting tribes. Thus, Congress can at times act as a regulator (of Indian tribes) and at times as a trustee. ${ }^{145}$

How far the Indian Commerce Clause power may extend, especially in areas beyond Indian Country, is a difficult question. ${ }^{146}$

141 See Matthew L.M. Fletcher, ICWA and the Commerce Clause, in FACING the Future: The Indian Child Welfare Act At 30 (Matthew L.M. Fletcher, Wenona F. Singel \& Kathryn R. Fort, eds., 2008).

142 Cotton Petroleum Corp. v. New Mexico, 490 U.S. 163, 192 (1989).

143 Gregory Ablavsky, Beyond the Indian Commerce Clause, 124 YALE L.J. 1012, 1050 (2015).

144 See Jack M. Balkin, Commerce, 109 Mich. L. REv. 1, 24-25 (2010) (arguing that the Indian Commerce Clause as interpreted by the first Congress in the early Indian Trade and Intercourse Acts gave Congress power reaching beyond the regulation of trade and commercial affairs with Indian nations).

145 See Alex Tallchief Skibine, Indian Gaming and Cooperative Federalism, 42 ARIZ. ST. L. J. 253, 267-69 (2010).

146 See Alex Tallchief Skibine, Tribal Sovereign Interests Beyond the Reservation, 12 LEWIS \& ClARK L. REV. 1003, 1040-41 (2008). See also Monica Haymond, Who's in and Who's out: Congressional Power over Individuals Under the Indian Commerce Clause, 102 VA. L. REV. 1589 (2016) (criticizing the new regulations (80 Fed. Reg. 10146 (2015)) issued pursuant to the Indian Child Welfare Act, 25 U.S.C. 1901-1963, and arguing that the power of Congress to include as Indians non-enrolled persons living outside Indian Country and having no tied to any tribal community is limited and may amount to racial classifications). 
For the purpose of this article, it is clear that it does extend to regulation of criminal activities within Indian Country. ${ }^{147}$ Although I stated earlier that the Mancari's Court sentence, to the effect that as long as the special treatment of Indians could be tied to Congress unique obligations towards Indians, such legislation would not be disturbed, ${ }^{148}$ is better understood as enumerating one way a statute concerning Indians can meet rational basis review, there is an alternative way to understand that sentence. I have argued elsewhere that cases like Mancari demonstrate that the Court has integrated the trust doctrine into the Constitution. ${ }^{149}$ In other words, the Court used the trust doctrine to expand Congress's power over Indian affairs beyond its normal Indian Commerce Clause boundaries. The expansion, however, is not infinite. The legislation has to be rationally tied to Congress's unique trust obligations towards the Tribes. My argument flowed from the language the Court used in Mancari where after first stating that "the plenary power of Congress to deal with the special problems of Indians is drawn both explicitly and implicitly from the Constitution itself," the Court identified only the Indian Commerce power and the various treaties signed with Indian nations as the formal sources of this plenary power. 150 However, the Court quoted from a previous case for the proposition that because the United States through wars "overcame the Indians and took possession of their lands," leaving them "helpless and in need of protection. ... Of necessity, the United States assumed the duty of furnishing that protection, and with it the authority to do all that was required to perform that [protection]." 151

One could ask: what if a law, enacted pursuant to the Indian Commerce Clause, discriminated more blatantly against Indians, such as the laws that used to forbid Indians from possessing liquor on Indian reservations? ${ }^{152}$ I have elsewhere taken the position that such law would still not be considered racial classifications

147 See United States v. Antelope, 430 U.S. 641, 646-48 (1977).

148 Morton v. Mancari, 417 U.S. 535, 555 (1974).

149 See Alex T. Skibine, Integrating the Indian Trust Doctrine into the Constitution, 39 TULSA L. REV. 247, 247 (2003-04).

150 Morton, 417 U.S. at 551-52.

151 Id. at 552 (quoting Board of County Commissioners v. Seber, 318 U.S. 705, 715 (1943)).

152 For a comprehensive history of the federal alcohol laws related to Indians, see Robert J. Miller and Maril Hazlett, The 'Drunken Indian:' Myth Distilled into Reality Through Federal Alcohol Policy, 28 ARIZ. ST. L. J. 229 (1996). 
demanding strict scrutiny. ${ }^{153}$ Such law, however, should be stricken under rational basis review, or a special version of rational basis review some have called "rational basis with bite."154 This enhanced rational basis review would be available if the classification was made out of animus towards the group or if the statute was aimed at impairing or denying important liberty interests to members of a disfavored group lacking political clout. As I explained, the three major differences between the enhanced version and regular rational basis review is that under enhanced review, courts will: (1) determine the real purpose behind the law, (2) look more closely at whether the claimed governmental interest is legitimate, and (3) Evaluate the court's record to determine if the means chosen are rationally related to achieving the real purpose behind the legislation.

Because Mancari can be understood as using the trust doctrine to either expand the Indian commerce power beyond regular "commerce" or uphold the different treatment of Indians under rational basis review, in the next section, I discuss what type of legislation can in fact be considered as having been enacted pursuant to Congress unique obligations towards the Indians.

\section{Defining the Extent of Congress's Unique Obligations towards the Indians under the Indian Trust Doctrine}

One could criticize the reliance on the Indian Trust Doctrine as a source of congressional power that is too vague. ${ }^{155}$ In other words, how can one know whether a statute was enacted for the benefit of Indians pursuant to Congress's trust obligations? One of the ambivalences concerning the trust doctrine is that there are two versions of it. According to Professor Mary Wood, the first version which she named the "sovereign trust doctrine," 156 originated with Justice Marshall's opinion in Cherokee Nation $v$. Georgia, 157 where he described Indian nations as "domestic dependent nations" and went on to say that the relationship

153 See Alex T. Skibine, Using the New Equal Protection to Challenge Federal Control over Tribal Lands, 36 PUB. LAND \& REsources L. REV. 3, 29 (2015).

154 See id. at 50-51

155 See id. at 36-37.

156 See Mary Christina Wood, Indian Land and the Promise of Native Sovereignty: The Trust Doctrine Revisited, 1994 UTAH L. REV. 1471, 1548 (1994).

157 Cherokee Nation v. Georgia, 30 U.S. 1, 15 (1831). 
between the United States and these dependent nations resembled that of a guardian to its ward.158 Professor Wood has called this version the "sovereign trust," because its main purpose was for the trustee, the United States, to protect the continued existence of the beneficiaries, the Indian nations, as self-governing sovereign entities.

Unfortunately, the second iteration of the doctrine which Professor Wood named the "guardian-ward" version, was not as charitable to Indian nations. It was developed during what is referred to as the Allotment Era, ${ }^{159}$ and its main purpose was to grant plenary authority to Congress not only over Indian Affairs but also over all the internal affairs of the tribes and their members. 160 As the Court famously stated in United States $v$. Kagama, "[t]hese Indian tribes are the wards of the nation. They are communities dependent on the United States. From their very weakness and helplessness, so largely due to the course of dealing of the Federal Government. ... there arises the duty of protection, and with it the power." 161 One of the many racist overtones of this version of the doctrine was that individual Indians were considered to be "wards" of the federal government because it was thought that they were too incompetent to manage their own personal affairs. ${ }^{162}$ So from a doctrine aimed at preserving Indian nations as self-governing entities, the doctrine was transformed as a tool to give Congress plenary authority over Indian people so they could be more easily assimilated into the dominant society. ${ }^{163}$

Eventually, the Allotment Policy was repudiated in the Indian Reorganization Act of $1934,{ }^{164}$ the plenary power of Congress over Indian tribes is no longer considered absolute power, ${ }^{165}$ and the United States has, since the late 1960's, adopted a policy of

158 Id. at 17.

159 See Judith V. Royster, The Legacy of Allotment, 27 ARIz. ST. L. J. 1, 10 (1995) (the allotment era took place between 1871 and 1928. Its main purpose was to break up the tribal land base by allotting tribal lands within Indian reservations and assign them to individual Indians so that they could become farmers and more ready to assimilate with the dominant culture).

$160 I d$. at 9 (in other words, the purpose was to extend the power of Congress beyond what was then considered to be the limit of the Indian Commerce power).

161 United States v. Kagama, 118 U.S. 375, 383-84 (1886).

162 For a recent article describing the racist roots of this second version of the doctrine, see Mary K. Nagle, Nothing to Trust: The Unconstitutional Origins of the Post-Dawes Act Trust Doctrine, 48 TULSA L. REV. 63 (2012).

163 See United States v. Sandoval, 231 U.S. 28, 46 (1913).

16448 Stat. 984-88 (1934) (codified as amended 25 U.S.C. § 461 et. seq.).

165 See Delaware Tribal Bus. Comm. v. Weeks, 430 U.S. 73, 84 (1977) (citing United States v. Alcea Band of Tillamooks, 329 U.S. 40, 54 (1946)). 
encouraging self-determination for Indian nations ${ }^{166}$ as exemplified by a 2011 Supreme Court case; ${ }^{167}$ however, the trust doctrine today is still very much a mixture of these two earlier versions. As such, it has been criticized by some scholars. ${ }^{168}$ Scholars who have favored the continued reliance on the trust doctrine have attempted to delimit its contours in an attempt to more precisely define Congress's unique obligations towards the Indians. Reid Chambers, for instance, has argued that the trust doctrine should be viewed primarily as a doctrine to protect and encourage tribal self-government. 169 Professor Mary Wood has argued that the purpose of the trust doctrine should be to protect the attributes of tribal sovereignty which she claims at a minimum include: 1. A stable and separate land base, 2. A viable tribal economy, 3. Tribal self-government, and 4. Indian Cultural vitality. ${ }^{170}$

In a 1980 case the Supreme Court carved some limits on the power of Congress to invoke the trust doctrine as a source of plenary authority that could be used to get around otherwise applicable constitutional limits. In United States $v$. Sioux Nation, ${ }^{171}$ The Court held that because the taking of the Black Hills from the Sioux Nation in South Dakota by the federal government was not made pursuant to the trust responsibility, the Sioux were owed just compensation under the Fifth Amendment. ${ }^{172}$ The Court

166 See Felix Cohen, Handbook of Federal Indian Law 97, 102 (1942) (the policy of Indian self-determination started to take shape in the early 1960's).

167 United States v. Jicarilla Apache Nation, 131 S. Ct. 2313, 2323-24 (2011) (holding that the United States was not analogous to a regular trustee with fiduciary duties defined by the common law of trust because the trust function performed by the United States for Indian tribes was a sovereign function subject to the plenary power of Congress).

168 See Kevin Gover, An Indian Trust for the Twenty-First Century, 46 NAT. Resources J. 317, 318 (2006); Stacey Leeds, Moving Toward Exclusive Tribal Autonomy over Lands and Natural Resources, 46 NAT. RESOURCES J. 439, 441 (2006).

169 Reid P. Chambers, Compatibility of the Federal Trust Responsibility with Self-Determination of Indian Tribes: Reflections on Development of the Federal Trust Responsibility in the Twenty-First Century, Rocky MTn. Min. L. Found. 1, 20 (2005).

170 See Mary C. Wood, Protecting the Attributes of Native Sovereignty: A New Trust Paradigm for Federal Actions Affecting Tribal Lands and Resources, 1995 UtAH L. Rev. 109 (1995); See also Wood, Indian Land and the Promise of Native Sovereignty: The Trust Doctrine Revisited, 1994 UTAH L. REV. 1471, 1473-74 (1994).

171 United States v. Sioux Nation of Indians, 448 U.S. 371, 371 (1980).

172 U.S. CONST. amend. V ("nor shall private property be taken for public use, without just compensation"); Sioux Nation of Indians, 448 U.S. at 407-08 (1980). 
stated "the question whether a particular measure was appropriate for protecting and advancing the tribe's interests, and therefore not subject to the constitutional command of the Just Compensation Clause, is factual in nature. The answer must be based on a consideration of all the evidence presented." 173

III. WHEN IT COMES TO FEDERAL CRIMINAL LAWS AFFECTING INDIAN COUNTRY, SHOULD THE TERM “INDIAN” BE LIMITED TO PEOPLE OFFICIALLY ENROLLED WITH INDIAN NATIONS?

\section{A. Determining Whether the Definition of Indian for the Purpose of Federal Criminal Statutes is a Racial or Political Classification}

In challenging the classification of "Indian" in the four federal statutes at issue here, a defendant would have to allege that he is being exposed to different rules than others because of his race or the race of his victim and therefore, strict scrutiny should be applicable. Using the test described in Part II, whether treating "Indians" differently amounts to a racial classification would depend on whether these statutes were enacted pursuant to the Indian Commerce clause. If they were, there are no racial classifications involved and rational basis, rather than strict scrutiny, applies.

The first versions of the Indian Country Crimes Act, which came into its final form in 1854, were contained in the early Indian Trade and Intercourse Acts, the first version of which was enacted in 1790.174 Many of the Acts' criminal provisions were attempts to codify provisions contained in treaties signed with the Indian nations, dealing with the punishment of interracial crimes committed in the Indian Country. ${ }^{175}$ As such, the ICCA is rationally related to the trust responsibility since it is an enforcement of the treaty obligations the United States has towards the Indian nations. To the extent the ICCA enforces crimes committed between Indian and non-Indians, it deals with relations between reservation Indians and outsiders and is, therefore, also within the Indian Commerce Clause even if one takes the position that such clause does not give Congress the

\footnotetext{
$173 I d$. at 415 .

174 Act of July 22, 1790, 1 Stat 137.

175 See Robert N. Clinton, Development of Criminal Jurisdiction Over Indian Lands: The Historical Perspective, 17 ARIz. L. REV. 951, 958-62 (1975).
} 
power to regulate the internal affairs of the tribes. ${ }^{176}$

The Major Crimes Act (MCA) presents more problems because the Court originally took the position that it could not have been enacted pursuant to the Indian Commerce Clause and used the trust doctrine to uphold its legitimacy. ${ }^{177}$ Today, while the power of the Federal government to enact federal criminal laws under the interstate Commerce Clause may be successfully challenged, 178 its power to do so under the Indian Commerce Clause seems, unfortunately, beyond doubt. As the Court stated "If anything, the Indian Commerce Clause accomplishes a greater transfer of power from the States to the Federal Government than does the Interstate Commerce Clause." 179 Noted scholars have, however, challenged the existence of a general federal police power over Indian tribes as a matter of original intent or textual analysis of the Constitution. ${ }^{180}$ I agree with their arguments. Therefore, prosecutions undertaken under the Major Crimes Act for a crime committed by a tribal member against a member of the same tribe may not involve the Indian commerce power. Under the thesis proposed in this article, if sections of the Major Crimes Act are beyond the power of Congress under the Indian Commerce Clause, the different treatment of Indians under these sections would amount to a racial classification and would be evaluated under strict scrutiny. While the United States may have many compelling interests in implementing such legislation, enforcing the trust responsibility should not be considered one of them. Many scholars and commentators have argued that the Major Crimes Act was not enacted pursuant to the modern version of the trust doctrine. ${ }^{181}$ In other words, it was not done to protect the attributes of tribal sovereignty. ${ }^{182}$ In effect, quite the contrary. As Professor Kevin Washburn once observed:

\section{[T]he Major Crimes Act was a monumental}

176 See supra, notes 131-32.

177 United States v. Kagama, 118 U.S. 375, 380 (1886).

178 See United States v. Lopez, 514 U.S. 549, 567-68 (1995); United States v. Morrison, 529 U.S. 598, 627 (2000).

179 Seminole Tribe v. Florida, 517 U.S. 44, 62 (1996).

180 See Philip P. Frickey, Domesticating Federal Indian Law, 81 Minn. L. Rev. 31, 55-57 (1996); Clinton, supra note 138, at 115-16.

181 See Troy A. Eid \& Carrie Covington Doyle, Separate but Unequal: The Federal Criminal Justice System in Indian Country, 81 U. CoLO. L. REV. 1067, 1071 (2010).

182 See Wood, The Trust Doctrine Revisited, supra note 170, at 1476. 
encroachment on the sovereign powers of Indian tribal governments and a tremendous expansion of federal authority over Indian tribes and Indian people. At the time, official federal policy was to destroy tribal governments and encourage assimilation of individual Indians into the larger society. ${ }^{183}$

Obviously, the MCA is not rationally related to the trust obligations that the United States has towards Indian nations.

There are no similar problems with the Duro Fix or the Indian VAWA Amendments, since both statutes reaffirmed the tribes' inherent sovereignty to prosecute non-member Indians and nonIndians. ${ }^{184}$ The two statutes are clearly within the bounds of the Indian Commerce Clause as they regulate the relations between the tribes and non-members. In addition, they are consistent with the trust doctrine as they were enacted to protect tribal selfgovernment. It is noteworthy that the Duro Fix was challenged on equal protection grounds in two Circuit Court of Appeals cases. ${ }^{185}$ Both cases upheld the Duro Fix against these equal protection attacks, ${ }^{186}$ but since both involved Indians who were bona fide members of other federally recognized Indian tribes, they are not relevant to the central issue discussed in this Article which is whether recognizing as "Indians" persons of Indian ancestry who are not members of any federally recognized Indian tribe creates a racial classification.

A Due Process/Equal Protection argument was recently invoked on behalf of such a group by Judge Robert Jones in Las Vegas Tribe of Paiute Indians v. Phebus. ${ }^{187}$ At issue in the case was whether the Las Vegas Paiute Tribe had jurisdiction, pursuant to the Durofix, to prosecute Phebus after the Tribe had just disenrolled him. The tribal court held that Tribal jurisdiction was limited to Indians who were enrolled tribal members in a federally recognized tribe. Therefore, the Las Vegas Paiute Tribe did not have criminal jurisdiction over Phebus since he was no longer enrolled with any

183 See Washburn, supra note 21 , at 783.

18425 U.S.C. $\$ 1301(2)$ (2012), 25 U.S.C. 1304 (2012).

185 See Means v. Navajo Nation, 432 F.3d 924 (9th Cir. 2005); Morris v. Tanner, 160 F. App'x 600, 601-02 (9th Cir, 2005) (affirming Morris v. Tanner, 288 F. Supp. 2d 1133 (D. Mont. 2003).

186 Means, 432 F.3d at 937; Morris, 160 F. App'x at 601-02.

187 Las Vegas Tribe of Pauite Indians v. Phebus, 5 F. Supp. 3d 1221, 1231 (D. Nev. 2014). 
Indian tribe. After the tribal court decision came down, the Tribe sued Phebus in Federal Court seeking a declaratory judgment that it still had criminal jurisdiction over him because even though Phebus was no longer an enrolled tribal member, he could still be an "Indian" for the purpose of the Duro Fix since that statute adopted the definition of Indian used under the Indian Major Crimes Act. 188

The Federal District Court disagreed with both the tribal court and the Tribe. It held that while tribal jurisdiction was not limited to enrolled tribal members, this Tribe could only prosecute Phebus if, under the second prong of the Bruce test, it could establish that Phebus was recognized as an Indian by a tribe other than the one that had just disenrolled him. ${ }^{189}$ The reasoning of the Judge as to why he reached that conclusion is far from pellucid. The Court first mentioned that the Supreme Court case which upheld the constitutionality of the Duro Fix never reached the merits of the Due Process and Equal Protection claim but only held that under its plenary power over Indian Affairs, Congress could affirm and recognize the inherent power of Indian tribes to prosecute nonmember Indians. ${ }^{190}$ Secondly, the court interpreted a Ninth Circuit precedent, Means v. Navajo Nation, ${ }^{191}$ to have taken the position that tribal prosecutions of non-member Indians under the Duro Fix were not in violation of the Equal Protection and Due Process clauses as long as the non-member Indian defendant was in fact an enrolled or de facto member of another tribe. ${ }^{192}$ It is true that the Means Court saw potentially some serious Equal Protection issues with including non-enrolled Indians as Indians for the purpose of the Duro Fix. However, since petitioner Russell Means was in fact an enrolled member of the Oglala Sioux Tribe, it concluded "We therefore can and do leave for another day the challenging question Bruce invites: whether a person who was racially Indian, but who was not enrolled or eligible for enrollment in any tribe, would be subject to tribal court jurisdiction." ${ }^{193}$

The Phebus court went on to conclude that it had "no problem

\footnotetext{
18825 U.S.C. $\$ 1301(2)$ (2012).

189 Phebus, 5 F. Supp. 3d at 1237 (the court also ruled that the issue of whether a defendant being tribally prosecuted under the Duro Fix is in fact an Indian under the Bruce test should have been submitted to the jury).

190 Id. at 1231-32, (discussing United States v. Lara, 541 U.S. 193, 209-10 (2014)).

191 Means, 432 F.3d at 929.

192 Id. at 933.

193 Id. at $934-35$.
} 
ruling that equal protection principles prevent a tribe's prosecution of a non-member whose only putative tribal affiliation is with the prosecuting tribe itself and where that tribe has in fact rejected or revoked the person's membership."194 Attempting to explain why he had "no problem" with this conclusion, the judge just stated "Under such circumstances, the political distinction that may be permissibly drawn between non-member Indians and non-Indians has been pulled away, leaving behind a purely racial distinction between Indians and non-Indians, which is a constitutionally impermissible basis for unequal treatment under the law."195

It is far from clear why a tribal prosecution of a disenrolled former member amounts to a racial classification in violation of the Equal Protection clause, while a tribal prosecution of another person who is not enrolled with any tribe (but was never disenrolled by the prosecuting tribe) and otherwise meets the Bruce two prong test, should be considered a political classification. It may very well be that the Judge just felt that a person who had just been disenrolled by the prosecuting tribe could not get a fair trial in that tribal court system. In other words, the holding seems to have more to do with due process and fundamental fairness than denial of equal protection based on race.

In conclusion, because it is clear that under the thesis proposed in this article, the ICCA, the Duro fix, the Indian VAWA Amendments, and unfortunately also the current doctrine, the MCA, were all enacted pursuant to the Indian Commerce power, they cannot be considered "racial" classifications under the theory presented in this article. As such, the strict scrutiny test is not applicable. If the classification at issue here, unenrolled persons of Indian ancestry, was challenged under the rational basis test, that group would have to show the following: First, that it is being treated differently than similarly situated individuals. Secondly, that the government does not have a legitimate interest in treating the group differently, or that treating the group differently is not rationally related to the accomplishment of the government's legitimate goal, purpose, or interest. Here, the government's interests, whether it is implementing treaty provisions as in the ICCA, maintaining law and order on Indian reservations as with

194 Phebus, 5 F. Supp. 3d at 1232.

195 Id. 
the MCA, or protecting tribal sovereignty as with the Duro Fix, are all legitimate.

The only remaining question is whether including as "Indians" non-enrolled people of Indian ancestry who have some political or social affiliation with a tribe is rationally related to the governmental interests of promoting law and order or tribal selfgovernment on Indian reservations. Making additional people subject to federal or tribal criminal jurisdiction can only bolster law and order or tribal sovereignty. Because the Bruce/Rogers test demands significant political or social affiliation with tribal communities, there does not appear to be anything arbitrary or irrational in including such people of Indian ancestry under the definition of "Indian" for the purpose of federal or tribal criminal jurisdiction in Indian Country.

A similar issue involving the Equal Protection clause arose in a case challenging the power of an executive agency, the Bureau of Indian Affairs (BIA), to deny Native Hawaiians the right to petition for federal acknowledgment as an Indian tribe under rules established by the agency. ${ }^{196}$ The Native Hawaiian plaintiffs argued that the BIA regulation denying them the right to petition, and thereby treating them differently than any other nonHawaiian indigenous group within the United States, amounted to racial discrimination and should therefore be reviewed under strict scrutiny. The Ninth Circuit disagreed. After distinguishing Rice $v$. Cayetano, ${ }^{197}$ which had held that a law giving voting preference to Native Hawaiians amounted to racial discrimination under the $15^{\text {th }}$ Amendment to the United States Constitution, 198 the Ninth Circuit held that refusing to allow native Hawaiian groups the right to petition for federal recognition as an Indian tribe did not amount to racial discrimination because "the recognition of Indian tribes remains a political, rather than racial determination. Recognition of political entities, unlike classifications made on the basis of race or national origin are not subject to heightened scrutiny." 199 Using the lesser standard of judicial review, the court held that "the unique history of Hawaii provide sufficient basis to sustain the regulation against an equal protection challenge under the highly deferential rational basis review." 200

\footnotetext{
196 Kahawaiolaa v. Norton, 386 F.3d 1271 (9th Cir. 2004).

197 Rice v. Cayetano, 528 U.S. 495 (2000).

198 Id. at 542 .

199 Kahawaiolaa v. Norton, 386 F.3d 1271, 1279 (9th Cir. 2004).

200 Id. at 1280.
} 
It has to be remembered that historically, Congress has been given a lot of leeway to determine who qualifies as an Indian and what groups qualify as Indian tribes for the purpose of the Indian Commerce Clause. The question was debated at length by the Court in United States v. Sandoval. 201 The issue in Sandoval was whether Congress had the power to enact laws restricting the liquor trade inside the lands of the Pueblos in New Mexico. ${ }^{202}$ Whether the power existed depended on whether the Pueblos were "Indians" and constituted Indian tribes for the purpose of the Indian Commerce clause since that is the constitutional clause giving Congress the power to enact such laws. In ruling that it was up to Congress to determine whether the Pueblos were Indians and constituted Indian tribes, the Court stated:

Of course, it is not meant by this that Congress may bring a community or body of people within the range of this power by arbitrarily calling them an Indian tribe, but only in respect of distinctly Indian communities the questions whether, to what extent, and for what time they shall be recognized and dealt with as dependent tribes requiring the guardianship and protection of the United States are to be determined by Congress, and not by the courts. ${ }^{203}$

For the Sandoval court, determining what groups qualified as tribes was intrinsically related to who qualified as an "Indian." Without any "Indian" to speak of, no group could qualify as an "Indian" tribe. 204 Sandoval came down just a few years after Montoya v. United States, where the Court had stated "By a 'tribe' we understand a body of Indians of the same or a similar race,

201 United States v. Sandoval, 231 U.S. 28, 38 (1913).

202 See Gerald Torres, Who is an Indian? The Story of United States $v$. Sandoval, in INDIAN LAW STORIES 109-45 (Kevin K. Washburn et al. eds., 2011) (for a comprehensive analysis of the background and issues presented in the case). 203 Sandoval, 231 U.S. at 46.

204 As insightfully noted by Professor Gerald Torres, the "fundamental error" in both the lower court's opinion in Sandoval as well as in the Supreme Court is that the opinions focused wrongly on whether the Pueblo people were racially "Indian" instead of focusing on whether the Pueblos were a nation. Torres, supra note 6, at 132 . As stated by Professor Torres, "The racialist thinking that percolates through this opinion (and through the Supreme Court's later opinion as well) is that the racial condition of the Pueblos is what determines their legal status." Id. 
united in a community under one leadership or government, and inhabiting a particular through sometimes ill-defined territory."205

\section{B. The Policy Perspective:}

The previous section has shown that there is very little likelihood that expanding the universe of "Indians" beyond formal tribal enrollment would be struck as unconstitutional. The question explored in this section is whether there are any policy reasons to restrict the definition of Indian to people who are enrolled in federally recognized Indian tribes.

Concerning the definition of "Indian" for the purposes of federal jurisdiction, in the first case to come with a multi factor test to determine whether someone met the second prong of the Rogers test, the court mentioned that:

Congress enacted [these] federal criminal statutes in pursuance of the federal trust relationship to fulfill three purposes: to prevent lawlessness in Indian country, to fill gaps in criminal jurisdiction, and to shelter Native Americans from the possible biases of local courts. A broad construction of "Indian" to extend federal criminal jurisdiction in Indian country benefits Native Americans by advancing these three goals. ${ }^{206}$

Yet, as discussed earlier, many pro-tribal scholars do not share the opinion that the Indian Major Crimes Act was enacted for the benefit of the Indians. ${ }^{207}$

It is true that from a law enforcement perspective, as one commentator argued, a broad definition of Indian would allow the federal government to crack down more efficiently on criminals. ${ }^{208}$ Because of prosecutorial discretion, if a perpetrator can escape federal jurisdiction by showing he is not an Indian, states may decide not to prosecute him. As recently stated by the Supreme

205 Montoya v. United States, 180 U.S. 261, 266 (1901).

206 St. Cloud v. United States, 702 F. Supp. 1456, 1462 (1988).

207 See discussion supra p. 29 \& notes 180-183.

208 See Brian L. Lewis, Do You Know What You Are? You Are What You Is; You Is What You Am; Indian Status for the Purpose of Federal Criminal Jurisdiction and the Current Split in the Courts of Appeals, 26 HARV. J. RACIAL \& ETHIC JusT. 241, 284 (2010). 
Court "Even when capable of exercising jurisdiction, however, States have not devoted their limited criminal justice resources to crimes committed in Indian country." 209 On the other hand, from a practical perspective, as another commentator noted, the bright line approach of only relying on formal membership rolls has its advantage. ${ }^{210}$ First, it would prevent the incongruous situation of having federal courts and mostly non-Indian juries decide who is an Indian. ${ }^{211}$ Also, alleged criminal defendants would not be able to use their status as Indian or not as a matter of legal strategy to dismiss a prosecution. ${ }^{212}$ Third, it would remove any doubts concerning the constitutionality of the classification since the term Indian would be limited to tribally enrolled Indians. ${ }^{213}$ In addition, as stated by Judge Ikuta in her Zepeda concurrence, "In holding that a person is not an Indian unless a federal court has determined that the person has an acceptable Indian 'blood quantum,' we disrespect the tribe's sovereignty by refusing to defer to the tribe's own determination of its membership rolls." 214 Finally, limiting the term to enrolled Indians would get rid of the inconsistencies among the various cases, as well as between the circuits, 215 and also the inherently unpredictable jury determinations on that issue

From a tribal perspective, it would be difficult to argue for a narrow definition of Indians under the MCA and ICCA without a corresponding transfer of jurisdiction to the tribes because under current law, just diminishing the jurisdiction of the federal government without more would not mean a corresponding increase in tribal jurisdiction, but an increase in state jurisdiction. ${ }^{216}$ In addition, because the Duro fix and the VAWA Amendments adopted the same definition of "Indian" as the Major Crimes Act, tribal prosecutors will probably want a broad definition of "Indian" for all three statutes. At least one scholar has argued, however, that the definition of "Indian" is flexible enough that it could be given a different interpretation for the

209 United States v. Bryant, 136 S. Ct. 1954, 1960 (2016).

210 See Katharine C. Oakley, Defining Indian Status for the Purpose of Federal Criminal Jurisdiction, 35 Am. INDIAN L. REV. 177, 206-07 (2011).

211 Id.

$212 I d$. at 207.

213 Id. at 207-08.

214 United States v. Zepeda, 792 F.3d 1103, 1119 (9th Cir. 2015).

215 See Lindsey Trainor Golden, Embracing Tribal Sovereignty to Eliminate Criminal Jurisdiction Chaos, 45 U. Mich. J. of L. REFORM 1039, 1062-63 (2012).

216 See discussion supra notes 31-39. 
purposes of the Duro fix and the Major Crimes Act, ${ }^{217}$ and that tribes should be free to come up with their own definition of "Indian" for the purposes of the Duro fix. While I agree that giving different meanings to the term "Indian" for the purpose of each statute would make a lot of sense from a policy perspective, I have some doubts that courts would find the actual working of the Duro fix flexible enough to allow for that possibility. ${ }^{218}$

In the end, whether Indian tribes should care whether alleged criminals of Indian ancestry who are not enrolled tribal members are prosecuted by the states instead of by the federal government or the tribes is a policy question which should be determined by each tribe. This Article takes the position that federal criminal jurisdiction over "Indians" should be limited to enrolled tribal members unless the tribe on whose land the crime was committed has come up with precise standards letting federal judges and juries know who else qualifies as an Indian for the purposes of federal criminal jurisdiction. ${ }^{219}$

\section{CONCLUSION}

In summary, this article has argued that, with the possible exception of the Indian Major Crimes Act, the classification of "Indian" for the purposes of the ICCA and the Duro fix is not "racial" even if it includes non-enrolled people of Indian ancestry with significant connections to tribal communities. Furthermore, the holding of the Zepeda court, that the first prong of the Rogers test could be satisfied by proof of blood quantum from any Indian tribe, recognized or not, is highly suspicious, seems to be arbitrary, and boosts the argument that the classification of "Indian" in such cases is a racial classification. The conundrum, evident in Zepeda, about what type of blood qualifies as Indian blood reinforces the argument that the first prong of the Rogers test should be eliminated, if not because of constitutional grounds, at least for

217 See Addie C. Rolnick, Tribal Criminal Jurisdiction Beyond Citizenship and Blood, 39 AM. INDIAN L. REV. 337, 398 ("It is odd to assume that the limits on federal jurisdiction must match the limits on tribal jurisdiction, as the two systems have very different purposes and histories.").

218 See, for instance, In Re Gervais, 402 F. Supp. 2d 1219, 1224-25 (2004) (finding, over tribal objections to the contrary, that the tribe had no criminal jurisdiction over the petitioner because he was not an "Indian" for the purposes of the Duro-fix).

219 See Rolnick, supra note 217, at 398-403 (describing current tribal practices and codes defining who is an Indian for purposes of tribal jurisdiction). 
policy reasons.

In a report highly critical of law and order on Indian reservations, the Indian Law and Order Commission, recommended among other things, that:

[A]ny Tribe that so chooses can opt out immediately, fully or partially, of Federal Indian country criminal jurisdiction and/or congressionally authorized State jurisdiction, except for Federal laws of general application. Upon a Tribe's exercise of opting out, Congress would immediately recognize the Tribe's inherent criminal jurisdiction over all persons within the exterior boundaries of the Tribe's lands . . . 220

The Report in effect argued in favor of a transfer of federal and state jurisdiction to the tribes. That conclusion had also been endorsed by various scholars and commentators. 221 Acknowledging the problems plaguing current law enforcement on Indian reservations, this article has argued that the universe of "Indians" for the purpose of federal jurisdiction should be limited to enrolled tribal members unless the relevant tribe has enacted precise standards delineating who is an Indian for the purpose of federal and tribal jurisdiction on its reservation.

220 Indian Law \& Order Comm'n, A Roadmap for Making Native America Safer, Report to the President \& Congress of the United States (November 2013), https://perma.cc/67R7-ABER.

221 See generally Kevin K. Washburn, Federal Criminal Law and Tribal SelfDetermination, 84 N.C. L. REv. 779, 854-55 (2006); Lindsey Trainor Golden, Embracing Tribal Sovereignty to Eliminate Criminal Jurisdiction Chaos, 45 U. MicH. J. OF L. REFORM 1039, 1069 (2012). 